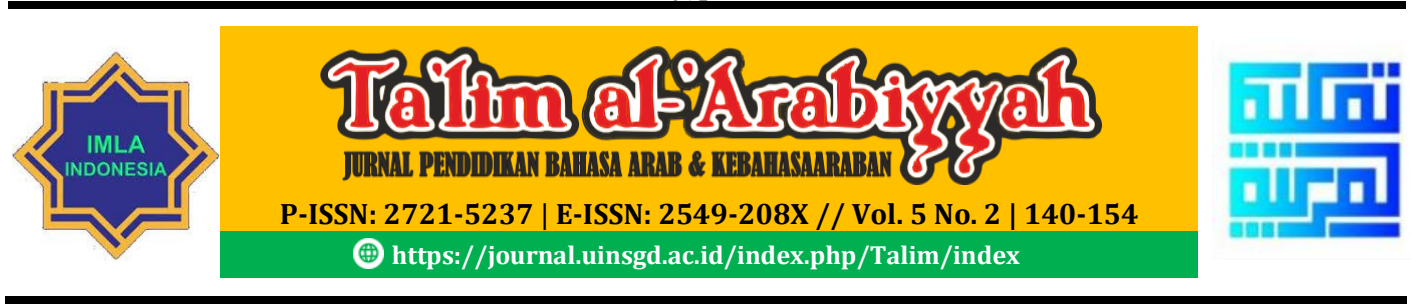

\title{
Pengembangan Materi Berbasis Komunikasi Bilingual Bagi Civitas Akademika UIN Maulana Malik Ibrahim Malang
}

\author{
Jumriyah $^{1}$, Usfiyatur Rusuly ${ }^{2}$ \\ ${ }^{1,2}$ Pusat Pengembangan Bahasa UIN Maliki Malang \\ Corresponding email: jumriyah_yusuf@,uin-malang.ac.id
}

\section{ABSTRACT}

UIN Maulana Malik Ibrahim Malang tries to be a World-Class University. One of the efforts to realize it is by a Multilingual Program course for the academic community mandated by the Center Language Development. This course requires relevant material to develop character participants and maximize learning and teaching. This study aims to describe the stages of developing bilingual communication-based materials. The development model used is the ADDIE model. The data analysis used is descriptive qualitative analysis technique and quantitative statistical analysis. The result is the development of bilingual communication-based materials with the ADDIE model with five stages, namely: (1) the analysis stage is student analysis, competency analysis, and material suitability analysis; (2) the design stage is compiling Arabic and English materials based on bilingual communication with the theme of daily life; (3) the development stage is validating and improving the product; (4) implementation stage is a limited trial; and (5) evaluation stage includes formative evaluation with the results of the assessment of Arabic material experts $85.3 \%$ (perfect), English material experts $85.3 \%$ (perfect), language learning design experts $78.4 \%$ (good), and the final result of the academic community's learning with an average score of 81 (very good).

Keywords: material development; bilingual communicattion; ADDIE

\section{ABSTRAK}

UIN Maulana Malik Ibrahim Malang sedang berupaya untuk menuju World Class University, salah satu upayanya adalah dengan diadakannya kursus Multilingual Program bagi civitas akademika, yang diamanhakan kepada Lembaga Pusat Pengembangan Bahasa. kursus ini memerlukan materi yang relevan dengan tujuan dan karakter peserta kursus untuk memaksimalkan proses belajar dan mengajar. Tujuan Penelitian ini untuk mendeskripsikan tahapan pengembangan materi berbasis komunikasi bilingual. Model Pengembangan yang digunakan adalah model ADDIE. Analisis data yang digunakan adalah teknik analisis deskriptif kualitatif dan analisis statistik kuantitatif. Hasil penelitian adalah pengembangan materi berbasis komunikasi bilingual dengan model ADDIE ada 5 tahap yaitu: (1) tahap analisis meliputi analisis pelajar, analisis kompetensi dan analisis kesesuain materi; (2) tahap desain yaitu menyusun materi Bahasa Arab dan Bahasa Inggris dengan basis komunikasi bilingual dengan tema kehidupan sehari-sehari; (3) tahap pengembangan yaitu memvalidasi dan memperbaiki produk; (4) tahap implementasi yaitu ujicoba terbatas; (5) tahap evaluasi meliputi evaluasi formatif dengan Hasil penilaian ahli materi bahasa Arab 85,3\% (sangat 
baik), ahli materi Bahasa Inggris 85,3\% (sangat baik), ahli desain pembelajaran bahasa 78,4\% (baik), dan hasil akhir belajar civitas akademik dengan nilai rata-rata 81 (sangat baik).

Kata Kunci: Pengembangan Materi; Komunikasi Bilingual; ADDIE.

\section{PENDAHULUAN}

Keanekaragaman bahasa menjadi tema unik yang sering dikaji dalam berbagai forum diskusi ilmiah, baik bahasa lokal daerah maupun bahasa asing internasional. AlQur'an sebagai sumber berbagai bidang ilmu juga menyebutkan fenomena aneka ragam bahasa bagi suku bangsa di dunia (QS. Ar-Ruum: 22). Eksistensi bahasa-bahasa menjadi sangat dibutuhkan karena ia merupakan media untuk berkomunikasi dan berinteraksi. Dengan melihat urgensi bahasa asing internasional, maka sangat wajar jika kita mendapati banyak institusi negeri maupun swasta yang mengadakan program-program peningkatan dan pemantapan untuk penguasaan bahasa tersebut bagi para pegawai, karyawan, tenaga pendidik atau kependidikan, serta mahasiswanya.

Diantara bahasa asing yang memiliki bargaining position dalam kancah dunia adalah bahasa Arab dan bahasa Inggris. Hal mendasar yang sering dijadikan alasan adalah karena dua bahasa ini merupakan bahasa asing internasional yang resmi dalam komunikasi di level organisasi dunia, yaitu Perserikatan Bangsa-Bangsa (PBB). Penutur bilingual sangat banyak jumlahnya di dunia, baik dari kalangan Native Speaker maupun Non-Native Speaker. Sehingga, para peminat atau pembelajar bahasa asing menjadikan dua bahasa ini sebagai pilihan untuk dipelajari dan dikuasai dalam merespon perkembangan zaman.

Sebagai alat komunikasi internasional, bahasa Arab dan Inggris tentunya memiliki peran penting untuk dijadikan media interaksi dengan orang lain, masyarakat dan suatu bangsa di berbagai belahan dunia. Dengan berbagai tujuan yang ingin dicapai dan dipenuhi oleh mayoritas orang, maka mereka berupaya untuk mempelajari dan mempraktikannya dalam berbagai even dan kegiatan. Demikian juga para warga kampus atau civitas akademik di Universitas Islam Negeri Maulana Malik Ibrahim Malang, mereka terus berupaya bagaimana bisa benar-benar menjadikan dua bahasa resmi internasional ini sebagai bahasa komunikasi di samping bahasa Indonesia. Apalagi dengan adanya sosialisasi surat edaran rektor Nomor: B1781/Un.03/OT.01.7/04/2019 tentang Multilingual Program di UIN Maulana Malik Ibrahim Malang Tahun 2019 dan himbauan untuk membentuk lingkungan bahasa dalam menyongsong World Class University (Surat Edaran Rektor Nomor: B1781/Un.03/OT.01.7/04/2019 Tentang Multilingual Program Di UIN Maulana Malik Ibrabim Malang Tabun 2019., 2019). Hal ini memperkuat adanya upaya yang sungguhsungguh untuk merealisasikan penguasaan bahasa asing internasional.

Pada faktanya, meskipun kampus dengan sebutan Bilingual atau Multilingual ini telah memberikan dukungan optimal atas terlaksananya program penerapan bahasa asing internasional di samping bahasa Indonesia, serta adanya berbagai upaya yang telah dilakukan untuk mendorong program penguasaaan bahasa asing internasional bagi warga kampus, namun di antara mereka masih ada yang belum optimal mempraktikkan bilingual, khususnya dalam berkomunikasi lisan sehari-hari di lingkungan kampus. Berdasarkan hasil observasi dan wawancara peneliti (Hasil Observasi Dan Wawancara 
Penulis Untuk. Analisis Kebutuhan Dalam Program Penguasaan Bahasa Asing Di Lingkungan UIN Maulana Malik Ibrabim Malang, 2021) ' Hal ini disebabkan adanya anggapan bahwa mereka merasa kurang percaya diri dan takut salah ketika menuturkan struktur kalimat bahasa asing, khususnya untuk materi bahasa Arab. Padahal untuk mempelajari bahasa, khususnya dalam berkomunikasi bagi pembelajar level dasar itu seseorang tidak harus fokus pada struktur kalimat.

Pembelajaran Bilingual di UIN Maulana Malik Ibrahim Malang memiliki karakteristik materi yang berbeda dengan yang lainnya. Di antara materi yang digunakan untuk praktik komunikasi Bilingual atau Multilingual di lembaga ini adalah "Buku Pintar; Ungkapan Praktis Bahasa Arab, Inggris, Mandarin, dan Persia" yang diterbitkan oleh UIN-Maliki Press. Buku ini disusun oleh para pengajar yang ahli dan berpengalaman dalam pengajaran bahasa Arab, Inggris, Mandarin, dan Persia sebagai bahasa kedua. Dari sisi konten, gambaran materi dari buku ini berisi tentang tema-tema yang dekat dengan ungkapan dalam kehidupan sehari-hari bagi civitas akademik UIN Maulana Malik Ibrahim Malang, sehingga dapat dipraktikkan dalam aktifitas keseharian (Hamid, \& dkk, 2018: 12).

Sebagai kampus Bilingual atau Multilingual, Pusat Pengembangan Bahasa Universitas Islam Negeri Maulana Malik Ibrahim Malang tentunya terus berupaya untuk melakukan peningkatan dan pemantapan program kebahasaan, diantaranya adalah dengan mendorong para dosen dan peneliti agar menghasilkan karya dan produk pengembangan materi untuk memenuhi kebutuhan warga kampus dan khalayak pada umumnya, dengan harapan dapat memperkaya khazanah keilmuan terkait pembelajaran pada bahasa asing. Oleh karena itu, pengembangan materi komunikasi bilingual (Bahasa Arab dan Bahasa Inggris) di UIN Maulana Malik Ibrahim Malang dipandang sangat perlu untuk mendorong mewujudkan pembelajaran yang efektif dan mudah dalam merealisasikan lingkungan bahasa asing internasional. Dengan adanya pengembangan materi berbasis komunikasi bilingual yaitu Bahasa Arab dan bahasa Inggris. Harapan dari pengembangan ini adalah dapat mengupayakan untuk meningkatkan kemampuan dan praktik komunikasi bilingual seluruh warga kampus atau civitas akademika UIN Maulana Malik Ibrahim Malang. Berdasarkan latar belakang di atas, penelitian tentang pengembangan materi komunikasi bilingual (Bahasa Arab dan Bahasa Inggris) bagi civitas akademika UIN Maulana Malik Ibrahim Malang.

Menurut Pusat Nasional Pelatihan Berbasis Kompetensi, materi adalah semua perangkat yang digunakan untuk memudahkan pelaksaaan proses pembelajaran guru dan murid di dalam kelas (Prastowo, 2011: 1). Menurut Widodo \& Jasmani, materi pendidikan adalah sekumpulan alat atau perangkat pembelajaran yang memuat materi, metode, batasan, dan metode evaluasi yang dirancang dengan sistematis dan menarik untuk mendapatkan tujuan yang diharapkan, yaitu tercapainya suatu kompetensi atau subkompetensi dalam segala kompleksitas yang ada (Lestari, 2013: 1). Menurut Pannen, materi merupakan materi mata pelajaran yang tersusun sistematis yang digunakan oleh guru dan siswa dalam proses pembelajaran (Tian, 2003: 13). Dalam dikmenjur.net, materi adalah beberapa materi atau materi (materi pendidikan) yang sistematis, yang menampilkan sejumlah kompetensi lengkap yang akan dipahami oleh siswa dalam kegiatan pembelajaran.

Dari beberapa pendapat ahli di atas dapat diambil kesimpulkan bahwa materi materi pendidikan adalah semua materi (informasi, alat dan teks) yang disusun dan 
digunakan secara sistematis dalam proses pembelajaran. Maka semua buku yang dijual bebas di pasaran tidak dapat dikatakan sebagai materi jika tidak disusun secara sistematis untuk memenuhi kebutuhan proses belajar dan mengajar. Menurut Prastowo, materi berdasarkan bentuknya memiliki beberapa jenis, yaitu: Materi cetak, materi dengar, materi pandang dengar, dan materi interaktif.

Setiap proses pembelajaran yang dilakukan di dalam kelas maupun di luar kelas memerlukan adanya komunikasi, baik komunikasi antara pendidik dan peserta didik, atau sesama peserta didik. Dalam komunikasi ini diperlukan bahasa sebagai alat penyampai pesan. Seperti mana ungkapan Marliani, "bahasa adalah alat komunikasi yang dapat diartikan sebagai tanda, gerak dan suara untuk menyampaikan isi pikiran kepada orang lain". Bilingual adalah suatu istilah yang merupakan padanan dari dwibahasa yang memiliki maksud penggunaan dua bahasa. Boomfield berpendapat bahwa bilingual adalah orang yang menguasai dua bahasa atau lebih seperti penutur asli (Bloomfield, 1993: 125). Orang yang bilingual dapat melakukan komunikasi dengan dua Bahasa yang berbeda atau lebih, dapat membedakan bunyi pengucapan, beberapa perbendaharaan kata dan struktur kalimat. McMaradalam Cummins \& Swain (Jim \& Merril, 1986: 37) mengungkapkan bahwa: "Bilingual adalah those who prosses at least one of the language skills even to a minimal degree in the second language".

Pada masa ini, hampir semua orang mampu menggunakan Bahasa lebih dari satu. Bahasa tersebut digunakan sebagai Bahasa komunikasi dengan elemen-elemen Bahasa seperti pertanyaan, penyataan, dan sebagainya. Bahasa akan mempunyai makna tersendiri setelah diucapkan sesuai dengan konteks yaitu kapan dan dimana Bahasa itu dituturkan. Sehingga terjadi kompetensi komunikatif yaitu penutur secara naluri memahami bahasa sesuai fungsi dan tujuan, latar belakang lawan bicara, formal dan tidak formal, jenisnya dan juga strategi komunikasi yang berbeda (Wicaksono, 2016: 60). Bilingual menajdi kebutuhan pada kondisi tertententu, baik pada kondisi formal maupun non formal. Bilingual mereka gunakan untuk kebutuhan komunikasi diberbagai tempat seperti sekolah, kampus, transaksi pertokoan, pertemuan resmi dan non resmi, dan sebagainya.

\section{METODE PENELITIAN}

Penelitian ini termasuk Penelitian dan Pengembangan yang digunakan peneliti untuk menghasilkan produk dan menguji kelaikan produk dengan hasil spesifik dan eksperimen yang efektif (Sugiyono, 2008: 297). Peneliti akan mengembangkan materi Bahasa Arab dan Bahasa Inggris berbasis komunikasi bilingual dengan model pengembangan ADDIE yang mempunyai lima tahap yaitu analisis (analysis), desain (design), pengembangan (development), implementasi (implementation) dan evaluasi (evaluation) (Robert Maribe, 2009; 5). Analisis data menggunakan teknik analisis deskriptif kualitatif dan analisis statistik kuantitatif. Instrumen penelitian menggunakan observasi dan wawancara. 
Ta'lim al-'Arabiyyah : Jurnal Pendidikan Bahasa Arab dan Kebahasaaraban, 5 (2), 2021

\section{HASIL DAN PEMBAHASAN}

Hasil dari penelitian dan pengembangan ADDIE ini adalah produk buku materi Bahasa Arab dan Bahasa Inggris berbasis Komunikasi Bilingual. Produk ini dikembangkan dengan pendekatan sistematis dalam pengembangan pembelajaran yaitu peneliti menghendaki materi yang dikembangkan sebagai materi utama yang digunakan dalam peningkatan kemampuan berbahasa Arab dan berbahasa Inggris bagi civitas akademik UIN Maulana Malik Ibrahim Malang yang meliputi, karyawan, pendidik dan tenaga kependidikan, serta satuan pengamanan. Berikut tahapan pengembangan dengan model ADDIE (Robert Maribe, 2009: 5; Wulan, 2019: 170) yang dilaksanakan peneliti tampak pada gambar 1 di bawah:

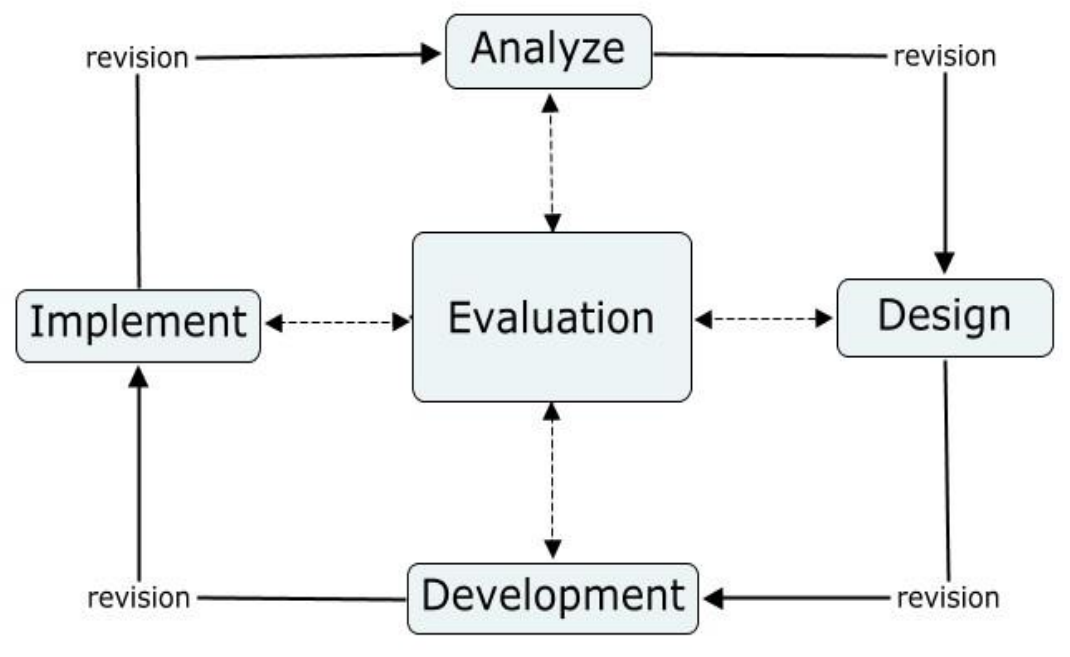

Gambar 1: Tahapan Penelitian dan Pengembangan Materi Berbasis Komunikasi Bilingual dengan Model ADDIE

\section{Tahap Analisis (Analyze)}

Tahap analisis meliputi analisis peserta didik, analisis kompetensi yang dituntut dari peserta didik, dan analisis materi yang sesuai dengan tuntutan kompetensi. Peserta didik di sini adalah civitas akademik UIN Maulana Malik Ibrahim Malang meliputi Karyawan, Pendidik dan Tenaga Kependidikan, termasuk satuan pengamanan. Pembelajaran Bahasa Arab dan Inggris ini berdasarkan surat edaran rektor Nomor: B1781/Un.03/OT.01.7/04/2019 tentang Multilingual Program di UIN Maulana Malik Ibrahim Malang Tahun 2019 dan himbauan untuk membentuk lingkungan bahasa dalam menyongsong World Class University, juga pembaharuan dan pengembangan bahan ajar yang sudah dibuat sebelumnya yaitu karangan Abdul Hamid dkk dengan bukunya berjudul: Buku Pintar; Ungkapan Praktis Bahasa Arab, Inggris, Mandarin, dan Persia. 2018. UIN-Maliki Press. Berdasarkan kebutuhan kompetensi civitas akademika yang diamati peneliti menunjukkan kurang optimal praktik bilingual dalam sehari-hari karena kurang percaya diri dan takut salah dari civitas akademika. 


\section{Tahap desain (Design)}

Berdasarkan analisis kebutuhan tersebut, peneliti menyusun materi Bahasa Arab dan Bahasa Inggris berbasis Komunikasi Bilingual dengan tema yang disesuaikan konteks (kehidupan sehari-hari) yaitu: At Ta'aruf I dan II (Introduction I dan II), Al Usrah I dan II (Family I dan II), Al Ansyitah Al Yaumiyyah I dan II (Daily Activity I dan II), Al Mibnah I dan II (Job I dan II), Fil Jami'ah I dan II (at The Campus I dan II), Fil Madrasab I dan II (at The School I dan II), Fil Fasl I dan II (at The Class I dan II), Fil Ma'had I dan II (at The Domatory I dan II), Fil Maktabah I dan II (in The Library I dan II). Subbab pada setiap bab yaitu kosakata, struktur kalimat sederhana, teks percakapan sederhana, latihan. Peneliti lampirkan bagian halaman pada materi pada Gambar 2.
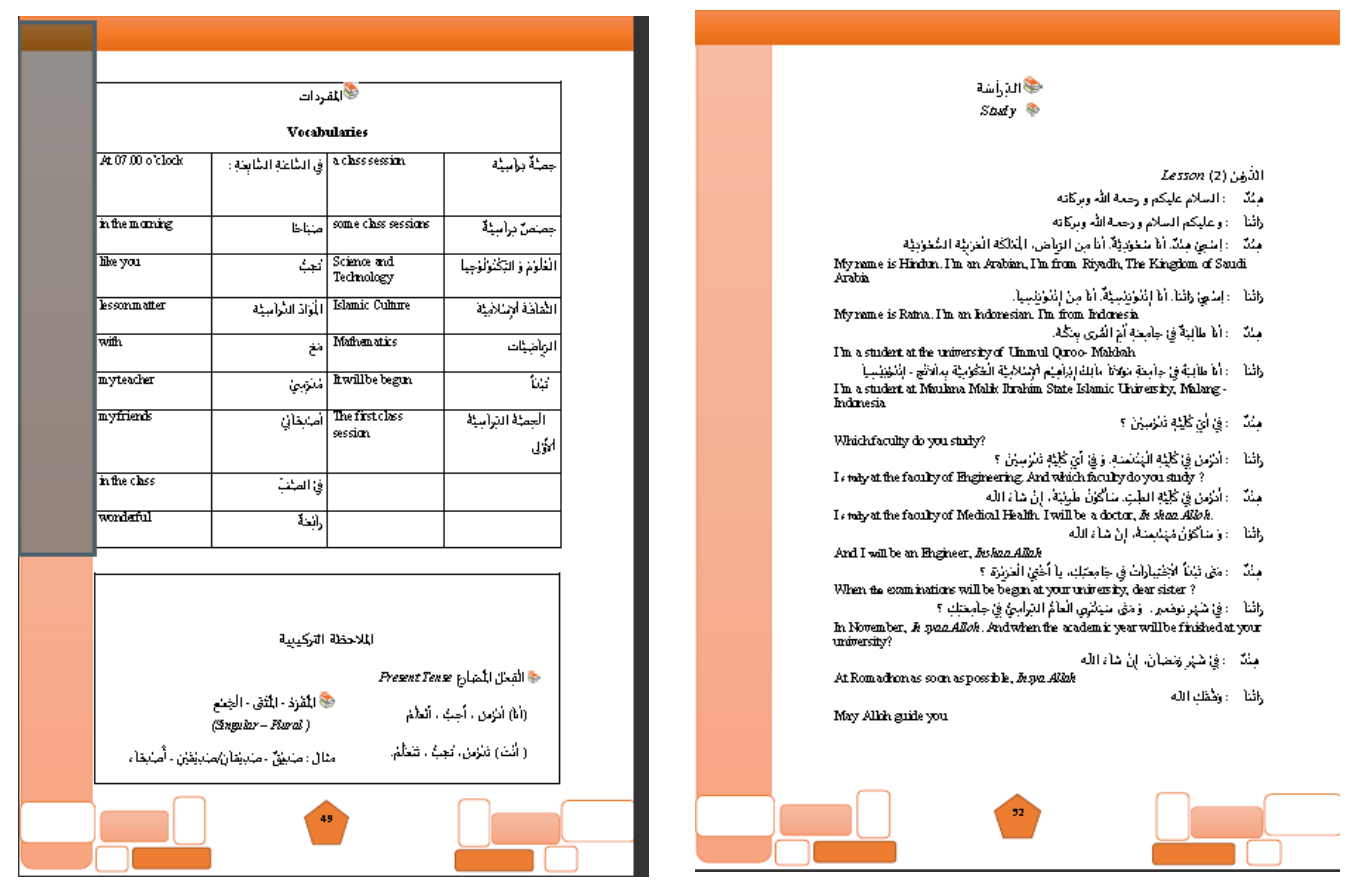

Gambar 2: Halaman Materi Bahasa Arab dan Bahasa Inggris Berbasis Komunikasi Bilingual yang dirancang dengan model ADDIE

\section{Tahap Pengembangan (Development)}

Pada tahap pengembangan Desain produk dilakukan 2 tahap yaitu: (1) peneliti kembali memeriksa materi yang akan divalidasi, dan (2) peneliti menyusun angket validasi untuk ahli media dan ahli materi, serta pendistribusiannya. Kemudian peneliti menghasilkan hasil penilaian para ahli berikut:

a. Validasi dari dosen ahli materi bahasa Arab.

Peneliti menggunakan rumus untuk mengetahui validitas materi tersebut, yaitu: $\frac{58}{68} \times 100 \%=85,3 \%$. Hasil penelitian di atas menunjukkan validitas produk dari ahli materi Bahasa Arab menghasilkan 85,3\% berarti sangat baik dan valid. Dan ahli materi Bahasa Arab memberikan saran dan masukan untuk materi ini sebagai berikut: (1) Harus ada petunjuk/ arahan pada setiap biwar, dan (2) Lebih 
Ta'lim al-'Arabiyyah : Jurnal Pendidikan Bahasa Arab dan Kebahasaaraban, 5 (2), 2021

bagus jika ditambah latihan hiwarnya, sehingga para civitas akademik bisa lebih banyak kosakata yang diperolehnya.

Adapaun hasil angket dapat dilihat pada tabel 1 berikut:

\section{Tabel 1: Hasil Validasi Dari Dosen Ahli Materi Bahasa Arab}

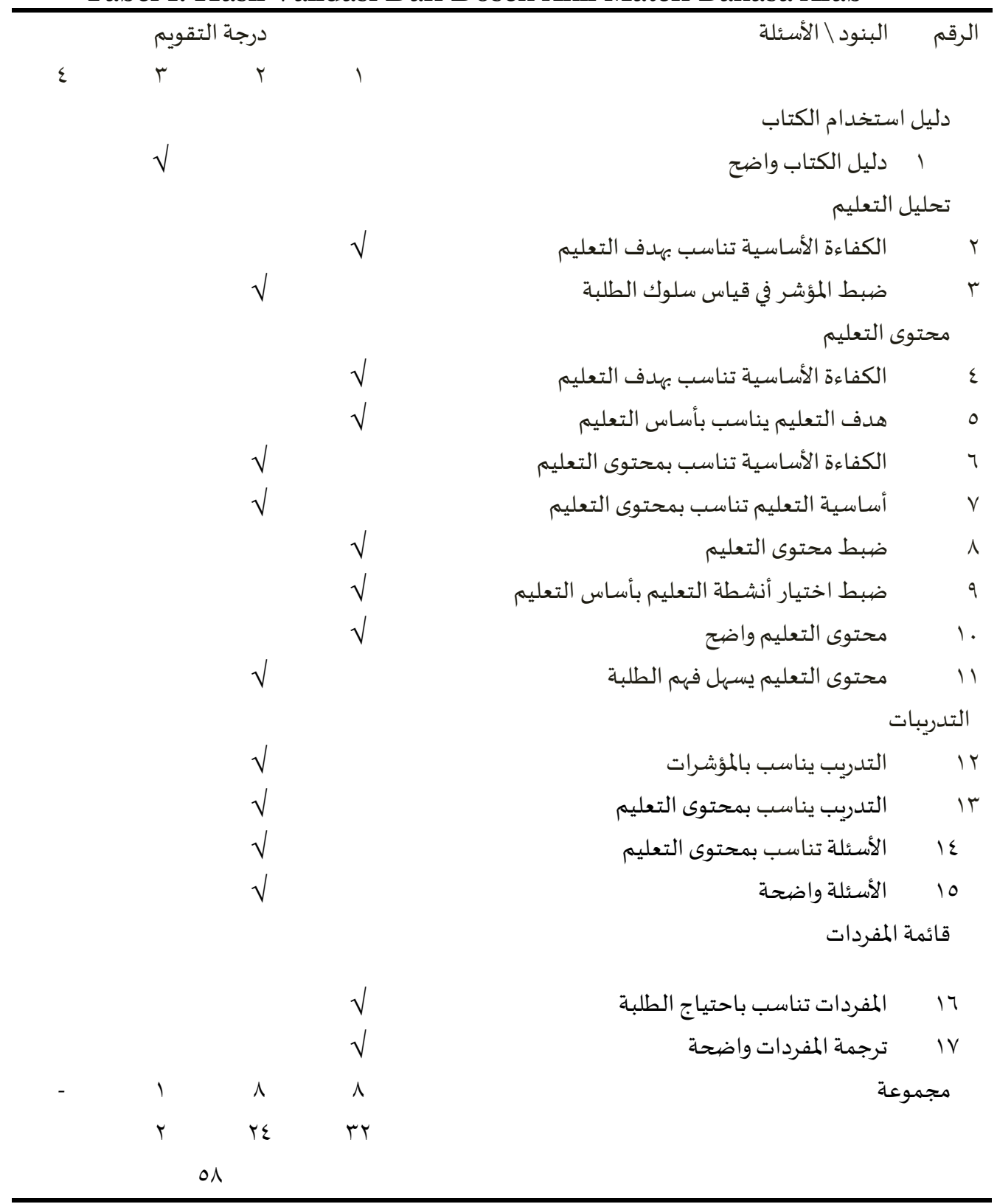


b. Validasi dari dosen ahli materi bahasa Inggris

Peneliti menggunakan rumus untuk mengetahui validitas materi tersebut, yaitu: $\frac{58}{68} \times 100 \%=85,3 \%$. Hasil penelitian di atas menunjukkan validitas produk dari ahli materi Bahasa Inggris menghasilkan 85,3\% berarti sangat baik dan valid. Ahli materi Bahasa Inggris memberikan saran dan masukan untuk materi ini sebagai berikut: (1) Menambah variasi dialog sehingga civitas akademik lebih banyak mendapatkan kosa kata; (2) Menambah variasi latihan yang membuat civitas akademik lebih percaya diri dalam praktek kosakata. Adapaun hasil angket dapat dilihat pada tabel 2 berikut:

Tabel 2: Hasil Validasi Dari Dosen Ahli Materi Bahasa Inggris

\begin{tabular}{|c|c|}
\hline \multicolumn{2}{|c|}{ No Items/ Questions } \\
\hline$\overline{\text { Man }}$ & al book use \\
\hline 1 & Clarity of the book's usage guide \\
\hline Edu & ation analysis \\
\hline 2 & $\begin{array}{l}\text { Appropriateness of core competency to } \\
\text { education objectives }\end{array}$ \\
\hline 3 & $\begin{array}{l}\text { The discipline of indicators in measuring the } \\
\text { behavior of pupils }\end{array}$ \\
\hline
\end{tabular}
Evaluation Degree $\begin{array}{llll}1 & 2 & 3 & 4\end{array}$

4 Appropriateness of core competency to education objectives

5 Appropriateness of education objectives with basic education

6 Appropriateness of basic competence to educational content

7 Essential occasion education content education

8 Discipline education content

9 Discipline for choosing educational activities as basic education

10 Clarity of education content

11 Ease of educational content for pupils' understanding

\section{Exercise}

12 Suitable exercises with indicators

13 Appropriateness of exercises with educational content

14 Appropriateness of questions to educational content

15 Clarity of questions

Vocabulary list

16 Appropriateness of the written vocabulary sentence for students' needs

17 Clarity of translation vocabulary 
c. Validasi dari dosen ahli desain pembelajaran

Peneliti menggunakan rumus untuk mengetahui validitas materi tersebut, yaitu: $\frac{279}{356} \times 100 \%=78,4 \%$. Hasil penelitian di atas menunjukkan validitas produk dari ahli desain pembelajaran menghasilkan 78,4\% berarti baik dan valid. Ahli desain pembelajaran memberikan saran dan masukan untuk materi ini sebagai berikut: (1) memperhatikan font dan ukuran tulisan; (2) spasi dan tab dirapikan; (3) menambahkan gambar agar lebih menarik. Adapun hasil angket dapat dilihat pada tabel 3 berikut:

Tabel 3: Hasil Validasi Dari Dosen Ahli Desain Pembelajaran

\begin{tabular}{|c|c|c|c|c|}
\hline \multicolumn{5}{|c|}{ Perwajahan Cover } \\
\hline 1 & Judul Jelas & & $\sqrt{ }$ & \\
\hline 2 & Tulisan Judul Menarik & & $\sqrt{ }$ & \\
\hline 3 & Tulisan Tepat dan betul & $\sqrt{ }$ & & \\
\hline 4 & Ukuran buku sesuai & & $\sqrt{ }$ & \\
\hline 5 & Ukuran huruf sesuai & & $\sqrt{ }$ & \\
\hline 6 & Jenis huruf tepat & & $\sqrt{ }$ & \\
\hline 7 & Paduan warna serasi & $\sqrt{ }$ & & \\
\hline 8 & Tebal kertas cover benar & & & $\sqrt{ }$ \\
\hline 9 & Kualitas cover & & & $\sqrt{ }$ \\
\hline 10 & Kualitas bentuk jilidan & & & $\sqrt{ }$ \\
\hline 11 & Tampilan huruf bagus & & $\sqrt{ }$ & \\
\hline 12 & Keindahan tampilan gambar & $\sqrt{ }$ & & \\
\hline 13 & $\begin{array}{l}\text { Bila pilihan alternatif pada angka } 1 \text { atau } 2 \text {, sa } \\
\text { komponen perwajahan adalah: sebaiknya ada } \\
\text { bagus lagi. }\end{array}$ & $\begin{array}{l}/ \mathrm{ko} \\
\mathrm{mb}\end{array}$ & tar & tang \\
\hline \multicolumn{5}{|c|}{ Halaman Judul } \\
\hline 1 & Tulisan jelas & & $\sqrt{ }$ & \\
\hline 2 & Ukuran huruf benar & & $\sqrt{ }$ & \\
\hline 3 & Tulisan tepat & & $\sqrt{ }$ & \\
\hline 4 & Jenis huruf sesuai & & $\sqrt{ }$ & \\
\hline 5 & Jarak spasi & $\sqrt{ }$ & & \\
\hline 6 & Kualitas kertas & & $\sqrt{ }$ & \\
\hline 7 & Tata letak (tepi buku) & & $\sqrt{ }$ & \\
\hline 8 & Struktur kalimat benar & & $\sqrt{ }$ & \\
\hline 9 & Tampilan menarik & $\sqrt{ }$ & & \\
\hline 10 & $\begin{array}{l}\text { Bila pilihan alternatif pada angka } 1 \text { atau } 2 \text {, sa } \\
\text { komponen halaman judul adalah: jarak spasi } \\
\text { kemenarikan tampilan dalam halaman judul m }\end{array}$ & $\begin{array}{l}/ \mathrm{ko} \\
\text { ih } \mathrm{l}\end{array}$ & tar & $\begin{array}{l}\operatorname{tang} \\
\text { Dan } \\
\text { ana. }\end{array}$ \\
\hline Kat: & ngantar & & & \\
\hline
\end{tabular}


Ta'lim al-'Arabiyyah : Jurnal Pendidikan Bahasa Arab dan Kebahasaaraban, 5 (2), 2021

\begin{tabular}{llr}
\hline 1 & Ketepatan penempatan & $\sqrt{ }$ \\
2 & Isi jelas & $\sqrt{ }$ \\
3 & Susunan kalimat jelas & $\sqrt{ }$ \\
4 & Mudah dipahami & $\sqrt{ }$ \\
5 & Tampilan menarik & $\sqrt{ }$ \\
6 & Bahasa sesuai dan benar & $\sqrt{ }$ \\
7 & Struktur Bahasa sederhana & $\sqrt{ }$ \\
8 & Ukuran huruf tepat & $\sqrt{ }$ \\
9 & Jenis huruf tepat & $\sqrt{ }$ \\
10 & Jarak spasi & Sistematika penulisan
\end{tabular}

12 Bila pilihan alternatif pada angka 1 atau 2, saran atau komentar Daftar isi tentang komponen kata pengantar adalah:

\begin{tabular}{llr}
\hline 1 & Ketepatan penempatan & $\sqrt{ }$ \\
2 & Isi jelas & $\sqrt{ }$ \\
3 & Susunan kalimat jelas & $\sqrt{ }$ \\
4 & Mudah dipahami & $\sqrt{ }$ \\
5 & Tampilan menarik & $\sqrt{ }$ \\
6 & Bahasa sesuai dan benar & $\sqrt{ }$ \\
7 & Struktur Bahasa sederhana & $\sqrt{ }$ \\
8 & Ukuran huruf tepat & $\sqrt{ }$ \\
9 & Jenis huruf tepat & $\sqrt{ }$ \\
10 & Jarak spasi & Sistematika penulisan
\end{tabular}

12 Bila pilihan alternatif pada angka 1 atau 2, saran/komentar tentang komponen petunjuk/panduan adalah:

Petunjuk penggunaan buku

\begin{tabular}{|c|c|c|}
\hline 1 & Ketepatan penempatan & $\sqrt{ }$ \\
\hline 2 & Isi jelas & $\sqrt{ }$ \\
\hline 3 & Susunan kalimat jelas & $\sqrt{ }$ \\
\hline 4 & Mudah dipahami & $\sqrt{ }$ \\
\hline 5 & Tampilan menarik & $\sqrt{ }$ \\
\hline 6 & Bahasa sesuai dan benar & $\sqrt{ }$ \\
\hline 7 & Struktur Bahasa sederhana & $\sqrt{ }$ \\
\hline 8 & Ukuran huruf tepat & $\sqrt{ }$ \\
\hline 9 & Jenis huruf tepat & $\sqrt{ }$ \\
\hline 10 & Jarak spasi & $\sqrt{ }$ \\
\hline 11 & Sistematika penulisan & $\sqrt{ }$ \\
\hline 12 & $\begin{array}{l}\text { Bila pilihan alternatif angka } 1 \text { atau } 2 \text {, saran/komentar } \\
\text { komponen petunjuk/panduan adalah: }\end{array}$ & r tentang \\
\hline \multicolumn{3}{|c|}{ Analisis program pembelajaran } \\
\hline 1 & Ketepatan penempatan & $\sqrt{ }$ \\
\hline 2 & Mudah dipahami & $\sqrt{ }$ \\
\hline 3 & Kejelasan isi & $\sqrt{ }$ \\
\hline
\end{tabular}


Ta'lim al-'A rabiyyah : Jurnal Pendidikan Bahasa Arab dan Kebahasaaraban, 5 (2), 2021

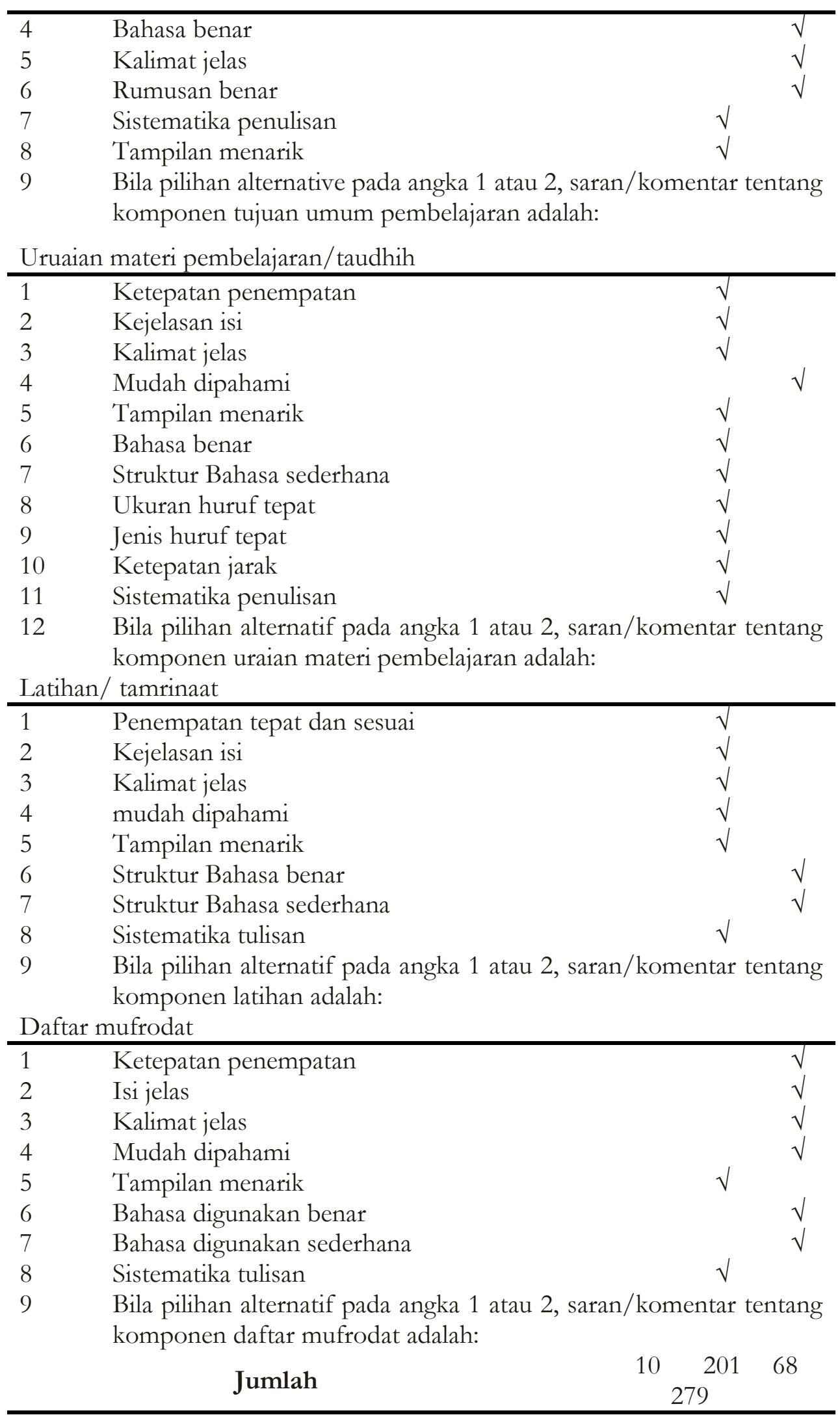


Ta'Cim al-'Arabiyyah : Jurnal Pendidikan Bahasa Arab dan Kebahasaaraban, 5 (2), 2021

\section{Tahap Implementasi (implementation)}

Materi Bahasa Arab dan Bahasa Inggris yang direvisi diujicobakan secara terbatas kepada 5 orang civitas akademik untuk mengetahui kelaikan produk materi yang dirancang, Skor hasil belajar dengan menggunakan materi ini dapat terlihat pada table 4.

Tabel 4: Skor Akhir Civitas Akademik dalam Ujicoba Materi Terbatas

\begin{tabular}{|c|c|c|c|c|}
\hline NO & Nama & Jabatan & $\begin{array}{l}\text { Skor } \\
\text { Akhir }\end{array}$ & Keterangan \\
\hline 1 & Hendra & Satuan pengamanan & 80 & $\begin{array}{l}\text { Mampu hafal } 20 \\
\text { kosakata perbab }\end{array}$ \\
\hline 2 & Fakih & Satuan pengamanan & 65 & $\begin{array}{l}\text { Mampu hafal } 13 \\
\text { kosakata perbab }\end{array}$ \\
\hline 3 & Muttahidah & $\begin{array}{l}\text { Kepala Subbaag } \\
\text { Akademik } \\
\text { Kemahasiswaan }\end{array}$ & 75 & $\begin{array}{l}\text { Mampu hafal } 20 \\
\text { kosakata perbab }\end{array}$ \\
\hline 4 & $\begin{array}{l}\text { Muhammad } \\
\text { Sholahuddin }\end{array}$ & Karyawan LP2M & 85 & $\begin{array}{l}\text { Mampu hafal } \\
\text { semua atau } 25 \\
\text { kosakata perbab }\end{array}$ \\
\hline 5 & $\begin{array}{l}\text { Achmad Dini } \\
\text { Hidayatullah }\end{array}$ & $\begin{array}{l}\text { Karyawan Akademik } \\
\text { Kemahasiswaan }\end{array}$ & 80 & $\begin{array}{l}\text { Mampu hafal } \\
\text { semua atau } 25 \\
\text { kosakata perbab }\end{array}$ \\
\hline 6 & Rahmat Basuki & $\begin{array}{l}\text { Karyawan Administrasi } \\
\text { Bagian Umum }\end{array}$ & 85 & $\begin{array}{l}\text { Mampu hafal } \\
\text { semua atau } 25 \\
\text { kosakata perbab }\end{array}$ \\
\hline \multicolumn{3}{|c|}{ Nilai Rata-rata } & 81 & Sangat Baik \\
\hline
\end{tabular}

\section{Tahap Evaluasi (Evaluation)}

Tahap yang terakhir yaitu melakukan evaluasi meliputi evaluasi formatif saja dengan tujuan untuk memperbaiki produk pengembangan yang didapatkan. Evaluasi dilihat dari hasil penilaian validator dan Skor hasil belajar dari civitas akademika UIN Malang dengan ujicoba terbatas. Hasil penilaian ahli bahasa Arab berdarkan angket tertutup meunjukkan bahwa prosentase yang diperoleh materi adalah $85,3 \%$ yang berarti sangat baik. Hasil penilaian ahli bahasa Inggris berdarkan angket tertutup meunjukkan bahwa prosentase yang diperoleh materi adalah $85,3 \%$ yang berarti sangat baik. Sedangkan hasil penilaian ahli bahasa desain pembelajaran berdarkan angket tertutup meunjukkan bahwa prosentase yang diperoleh materi adalah 78,4\% yang berarti baik. Dan hasil belajar civitas akademik pada ujicoba terbatas menunjukkan nilai rata-rata 81 yang berarti sangat baik.

Penelitian pengembangan materi Bahasa Arab dan Bahasa Inggris berbasis Komunikasi Bilingual untuk civitas akademika UIN Malang adalah berbeda dari penelitian sebelumnya, karena mencoba fokus pada kajian pengembangan bilingual pada aspek komunikasi bahasa Arab dan Inggris dengan penyajian materi komunikasi Bahasa Arab dan Bahasa Inggris secara bersamaan, kemudian penambahan struktur kalimat dalam bentuk tabel analisis sederhana untuk membantu para civitas akademika yang sedang belajar dalam mempraktikkan komunikasi dengan mengikuti contoh pola kalimat 
yang ada, serta melengkapi kalimat dengan kosakata (Bahasa Arab dan Bahasa Inggris) terkait tema untuk memudahkan pemahaman makna. Pengembangan materi seperti ini diharapkan menjadi materi bilingual yang dapat mengurangi rasa tukut salah ketika mempraktikkan komunikasi. Hal ini menjadi syarat mendasar bagi materi ajar yang dikembangkan yaitu materi ajar bersifat factual, bermanfaat, dibutuhkan, dan terperinci, materi ajar merupakan ilmu pengetahuan yang didapat dari hasil belajar, menghasilkan pengalaman atau kegiatan baru dalam proses belajar (Majid \& Handayani, 2004; 40-44) serta materi ajar sebagai informasi menyeluruh untuk pelajar dan media komunikasi anatara pelajar dan pendidik (Nor, 2018: 1-14).

Pengembangan materi ini dapat menjadi buku pendamping dan secara bertahap menjadi buku acuan utama dalam pembelajaran bilingual (Bahasa Arab dan Bahasa Inggris) untuk civitas akademika UIN Maulana Malik Ibrahim Malang. Meskipun pada awal pelaksanaan pembelajaran ini sebagai realisasi surat edaran rektor Nomor: B1781/Un.03/OT.01.7/04/2019 tentang Multilingual Program di UIN Maulana Malik Ibrahim Malang Tahun 2019 dan himbauan untuk membentuk lingkungan bahasa dalam menyongsong $W$ orld Class University yang membiasakan semua masyarakat UIN Maulana Malaik Ibrahim Malang menggunakan Bahasa Arab dan Bahasa Inggris di area lingkungan kampus. Pelaksanaannya pun langsung diamanahkan kepada Lembaga Pusat Pengembangan Bahasa yang pada pendiriannya masih memiliki empat unit pengembangan pembelajaran bahasa Asing dan pembelajaran bahasa Indonesia, yaitu BIPA (Bahasa Indonesia bagi Penutur Asing), PKPBI (Program Khusus Pembelajaran Bahasa Inggris), PKPBA (Program Khusus Pembelajaran Bahasa Arab), Pembelajaran Bahasa Persia, dan CLCC (Chinese Language and Culture Center) (Hamid \& Fatimah, 2020: 47). Keempat unit Lembaga ini melayani pelajar dari mahasiswa, bukan dari kalangan civitas akedemika. Di sinilah tantangan lembaga ini dalam proses pengembangan pembelajaran Bahasa Asing bagi pelajar dewasa untuk civitas akademika terutama pada bahan ajar yang digunakan.

Pemadanan kata Bahasa Arab dan Bahasa Inggris dalam satu paragraf atau dalam satu teks menjadi sangat penting untuk dilakukan sebagai variasi model pembelajaran untuk civitas akademika atau pembelajaran orang dewasa di UIN Maulana Malik Ibrahim Malang, sebagai cara memudahkan belajar Bahasa Asing dan menambah minat pelajar secara penyajian singkat untuk penyampaian materi kosakata Bahasa Asing yaitu Bahasa Arab dan Bahasa Inggris (Setyorini, 2015: 90). Pengembangan materi ini unik dan menarik, serta diharapkan dapat digunakan sebagai referensi materi-materi komunikasi dengan menggunakan Bahasa Arab dan Inggris (Bilingual) dengan tema kehidupan sehari-sehari dan sesuai konteks, juga dapat memberikan kontribusi positif bagi Pusat Pengembangan Bahasa UIN Maulana Malik Ibrahim Malang dan lembaga pendidikan lainnya pada lingkup UIN Maulana Malik Ibrahim Malang dalam membuat kebijakan strategis yang terkait dengan pengembangan materi atau bahan ajar berbasis komunikasi bilingual yaitu bahasa Arab dan Bahasa Inggris. Materi tersebut sangat layak sekali untuk digunakan sebagai acuan dalam pembelajaran bahasa Asing berbasis komunikasi bilingual, karena materi tersebut memiliki kualitas yang sangat praktis dan mudah untuk digunakan. 


\section{SIMPULAN}

Langkah-langkah pengembangan materi dan kelaikannya berbasis komunikasi bilingual. Model Pengembangan yang digunakan adalah model ADDIE yaitu: (1) tahap analisis meliputi analisis pelajar, analisis kompetensi yang dituntut dari pelajar, dan analisis materi yang sesuai dengan tuntutan kompetensi; (2) tahap desain yaitu menyusun materi Bahasa Arab dan Bahasa Inggris dengan basis komunikasi bilingual dengan tema yang disesuaikan konteks (kehidupan sehari-hari) yaitu: perkenalan, Keluarga, Kegiatan sehari-hari, di kampus, di sekolah, di kelas, di mahad, di perpustakaan; (3) tahap pengembangan yaitu memvalidasi dan memperbaiki produk dengan peneliti kembali memeriksa materi yang akan divalidasi, dan peneliti menyusun angket validasi untuk ahli media dan ahli materi, serta pendistribusiannya; (4) tahap implementasi yaitu ujicoba terbatas pada pelajr dewasa (6 orang civitas akademika) dengan menghasilkan skor hasil akhir belajar; (5) tahap evaluasi meliputi evaluasi formatif dengan Hasil penilaian ahli bahasa Arab berdarkan angket tertutup meunjukkan bahwa prosentase yang diperoleh materi adalah 85,3\% yang berarti sangat baik. Hasil penilaian ahli bahasa Inggris berdarkan angket tertutup meunjukkan bahwa prosentase yang diperoleh materi adalah 85,3\% yang berarti sangat baik. Sedangkan hasil penilaian ahli bahasa desain pembelajaran berdasarkan angket tertutup meunjukkan bahwa prosentase yang diperoleh materi adalah 78,4\% yang berarti baik. Dan hasil belajar civitas akademik pada ujicoba terbatas menunjukkan nilai rata-rata 81 yang berarti sangat baik.

\section{REFERENSI}

Bloomfield. 1993. Language. Hott Rinehart and Wistons.

Hamid, A., \& dkk. 2018. Buku Pintar; Ungkapan Praktis Bahasa Arab, Inggris, Mandarin, dan Persia. Malang: UIN-Maliki Press.

Hamid, M. A., \& Fatimah, S. 2020. Development of Arabic Conversation Material Based on Communicative-Interactive Approach/ Pengembangan Materi Percakapan Bahasa Arab Berbasis Pendekatan Komunikatif-Interaktif Bagi Mahasiswa. Ijaz. Arabi Journal of Arabic Learning, 3(1). https://doi.org/10.18860/ijazarabi.v3i1.8174

Hasil Observasi dan wawancara penulis untuk analisis kebutuban dalam program penguasaan bahasa Asing di lingkungan UIN Maulana Malik Ibrahim Malang. (2021).

Jim, C., \& Merril, S. 1986. Bilingualism in Education. Longman.

Lestari, I. 2013. Pengembangan Materi Berbasis Kompetensi. Padang: Akademia Permata.

Majid, A., \& Handayani, D. 2004. Pendidikan Islam berbasis Kompetensi, konsep dan Implementasi Kurikulum. Bandung: PT Remaja Rosdakarya.

Nor, F. 2018. Tashmim Al Manhaj Wa Kitab Ta'lim Al Lughah Al Arabiyah Lil Marhalab Al Jami'iyah Fi Dhaui Ma'ayiir Al Ithor Al Wathany Al Indunisy Lil Muahbilat (KKNI). 
Ta'lim al-'Arabiyyah : Jurnal Pendidikan Bahasa Arab dan Kebahasaaraban, 5 (2), 2021

Ijaz. Arabi Journal of Arabic Learning, 1(1). https://doi.org/10.18860/ijazarabi.v1i1.4942

Prastowo, A. (2011). Panduan Kreatif Membuat Materi Inovatif. Yogyakarta: Diva Press.

Robert Maribe, B. (2009). Instructional Design: The Addie Approach. Springer.

Setyorini, I. (2015). Nimasi Interaktif Kosakata Dalam Dua Bahasa (Arab-Inggris) Pada RA Kuwait Pusdiklat Dewan Da'wah Bekasi. BINA INSANI ICT JOURNAL, 2(2), 85-100. http://ejournal-binainsani.ac.id/index.php/BIICT/article/view/788

Sugiyono. (2008). Metode Penelitian Kuantitatif Kualitatif dan R \& D. Bandung: Alfabeta.

Surat Edaran Rektor Nomor: B-1781/Un.03/OT.01.7/04/2019 tentang Multilingual Program di UIN Maulana Malik Ibrabim Malang Tabun 2019. (2019).

Tian, B. (2003). Pengembangan Materi. Universitas terbuka.

Wicaksono, A. (2016). Teori Pembelajaran Bahasa: Suatu Catatan Singkat. Yogyakarta: Garudhawaca.

Wulan, N. (2019). Wulandari, N. (2019). Pengembangan Buku Saku Intensifikasi Bahasa Arab di IAIN METRO dengan Menggunakan Model ADDIE. Alfathin: Jurnal Bahasa Dan Sastra Arab, 1(2), 165-178. https://ojs.metrouniv.ac.id/index.php/alfathin/article/view/1272 